\title{
OXFORD OPHTHALMOLOGICAL CONGRESS
}

\section{ANNUAL MEETING, 1951}

THE 36th Annual Meeting of the Oxford Ophthalmological Congress was held at the School of Geography, Mansfield Road, Oxford, on July 5, 6, and 7 under the mastership of Mr. F. A. Anderson. Rooms had been arranged at Frewin Hall for lady ophthalmologists, and most of the men stayed in Brasenose College. Opportunity was given to visit the new out-patient department of the Oxford Eye Hospital throughout the Congress, and there was also a commercial exhibition of optical and surgical instruments each day. A golf contest was held at Frilford Heath on the evening of July 5, after a delightful tea party in the garden of St. John's College. In the Deer Park of Brasenose another tea party took place on July 6, so that members are indebted to the Presidents of these two colleges for much lively enjoyment.

Mr. Ian C. Fraser, the Honorary Secretary and Treasurer of the Congress, had generously applied himself to the task of ensuring the comfort of visitors and members, and he deserves to be congratulated upon the results of his activity. At the Annual Dinner held in the Hall of Brasenose College on July 6, Dr. Edmund B. Spaeth (Philadelphia,.U.S.A.) praised the informality of the atmosphere, and he protested that he had never attended a more friendly congress. His feelings were reciprocated, because he in his turn largely contributed to the success of the meeting. Some of us had been privileged to see his work and to receive his welcome in Philadelphia; and of course his monumental book on operative surgery was already familiar to ophthalmologists throughout and beyond the English-speaking world. Therefore Dr. Spaeth's paper, "The Surgical Correction of Complicated Congenital Blepharoptosis" had been impatiently awaited. In the event it proved to be a masterly and wellillustrated exposition, which will repay close study when the transactions are published. Another guest-speaker was Dr. J. L. Halliday (Glasgow), who was the first of three opening speakers in the discussion on "Ophthalmology and Psychosomatic Medicine". His discourse was lucid, forcible, and packed with common-sense, as might well have been expected from a study of his excellent writings. Professor W. J. B. Riddell (Glasgow) and Dr. Dorothy Campbell (Coventry) were the other openers. Papers were also contributed by Mr. Humphrey Neame (London), Mr. A. B. Nutt (Sheffield), Mr. G. T. Willoughby Cashell (Reading), Mr. L. E. Werner and Mr. T. J. Macdougald (Dublin), Mr. J. P. Francis 
Lloyd (Oxford), Mr. H. E. Hobbs and Mr. Charles Cook (London), Mr. R. Lang (Guildford), Mr. A. C. L. Houlton, Mr. C. R. S. Jackson, Dr. Mary Coxon, and Dr. B. A. Bembridge $(O x$ ford $)$, Mr. Harold Ridley (London), Mr. R. S. MacLatchy (Banbury), and Air Commodore J. C. Neely (London). On the last day of the Congress a discussion on "Modern Treatment of Detachment of the Retina" was opened by Mr. Seymour Philps (London), Mr. A. G. Cross (London), and Mr. R. I. T. Lloyd (Bradford).

The Doyne Memorial Lecture given by Mr. John Foster (Leeds) was a feat of endurance, a mine of information, and a storehouse of suggestive material for future discussions. For nearly two hours he regaled us with a multitude of ingenious devices applicable to hospital management, operative treatment, and clinical examination, punctuating his remarks with epigrammatic sallies. To summarize this concentrated material would be inappropriate, but it seems fitting to emphasize how tremendous must have been the labour of preparation. Mr. Foster testified to the help he had received from Nuffield Trust investigators, but even so, it was abundantly evident that every paragraph of this lecture had entailed hours of application. Once again Mr. Foster has shown what can be done by dexterity and inventiveness allied with an insatiable appetite for work.

J. H. DOGigiarI

\section{AMERICAN OPHTHALMOLOGICAL SOCIETY}

OFFICERS, 1951-1952

THF following officers have been elected for 1951-1952:

President: - - Dr. Lawrence T. Post
Vice-President: - Dr. Conrad Berens
Secretary-Treasurer: Dr. Maynard C. Wheeler
Editor: $\quad$ - Dr. Gordon M. Bruce.

\section{HONOURS}

Mr. James Andrew Craig, F.R.C.S. received the honorary degree of M.D. at the summer graduation ceremony of Queen's University. Belfast, for his long and distinguished service to the university as Lecturer in Ophthalmology. 